\title{
Behavioral Changes of Independent Palm Smallholders Farmers through Farmer Institution
}

\section{Perubahan Perilaku Petani Kelapa Sawit Swadaya melalui Kelembagaan Petani}

\author{
Nurliza $^{1, *)}$, Fauyan $^{2}$ \\ ${ }^{1}$ Agribusiness Department, Agriculture Faculty, Universitas Tanjungpura, Pontianak 78124, Indonesia \\ ${ }^{2}$ Dinas Pertanian dan Ketahanan Pangan, Kabupaten Sambas 79462, Indonesia \\ ${ }^{*}$ E-mail korespondensi: nurliza.spmm@gmail.com
}

Diterima: 16 Juli 2020 | Disetujui: 9 Februari 2021 | Publikasi Online: 17 Februari 2021

\begin{abstract}
Farmer institutions along with regulatory, normative, and cultural cognitive aspects have important roles in social cohesion to achieve the food security of independent palm smallholder farmer households. However, some dysfunctionalities and external challenges affect the structure of their institutions. This paper aims to find ways to change the behavior of independent palm smallholder farmers by identifying the internal and external factors of their behaviors in their institutions. The data were collected from 100 smallholders in West Kalimantan using Structural Equation Model (SEM). The results indicate that the internal factors do not influence farmers' behavior because of lack of social influences on their relationships, exceptional characteristics of the region, and a mismatch between perceived risk sources and risk management strategies. Meanwhile, the external factors (the surrounding environment, institutional information, the extension roles, ISPO, reward, and family encouragement) show positive influences on farmers' behavior. Therefore, to optimize the behavioral changes of independent palm smallholders in their institutions, knowledge exchange is necessary through formal or informal communication networks. Also, they need to have the connections with institutional buyers and potential agroprocessing entrepreneurs and the connection with appropriate formal saving schemes, and financial products in their value chains.
\end{abstract}

ABSTRACT

Keywords: farmers' institutions, independent palm smallholders', internal and external factors of behavior

\section{ABSTRAK}

Kelembagaan petani memiliki peran penting dalam sosial kohesif bersama elemen kognitif regulasi, normatif, dan budaya untuk mencapai ketahanan pangan rumah tangga petani sawit swadaya. Namun, ada disfungsionalitas dan tantangan eksternal yang mengubah struktur institusi petani tersebut. Oleh sebab itu, tujuan penelitian adalah bagaimana mengubah perilaku petani sawit swadaya dengan menguraikan faktor internal dan eksternal perilaku dalam kelembagaan petani. Data diperoleh dari 100 petani sawit swadaya di Kalimantan Barat menggunakan wawancara mendalam dengan Model Persamaan Struktural (Structural Equation Modelling/SEM). Hasil penelitian mengkonfirmasi bahwa faktor internal tidak memiliki pengaruh karena pengaruh sosial tidak mempengaruhi hubungan antar petani dalam institusi, karakteristik wilayah, dan ketidakcocokan antara sumber risiko yang dirasakan dan strategi manajemen risiko. Sementara itu, faktor eksternal berpengaruh positif pada perilaku petani karena lingkungan sekitar, diikuti oleh informasi kelembagaan, peran penyuluhan, ISPO, penghargaan, dan dorongan keluarga. Oleh sebab itu, optimalisasi perubahan perilaku petani swadaya dalam kelembagaan memerlukan adanya pertukaran pengetahuan melalui komunikasi jaringan formal atau informal; hubungan dengan pembeli institusional dan pengusaha agro-processing potensial; hubungan dengan skema tabungan formal yang tepat dan produk keuangan dalam rantai nilainya.

Kata kunci: kelembagaan petani, petani sawit swadaya, faktor internal and eksternal perilaku 


\section{INTRODUCTION}

Independent smallholders in Indonesia are the key to sustainability because since 22.22 percent or 2.5 million hectares of all palm oil plantations in Indonesia are being managed by independent smallholders. However, independent smallholders have limited support in training and information on good agricultural practices and supervision from the government, companies, and financial institutions. Aware of the need to seek support, some the independent palm smallholders recently joined farmer institutions (i.e. farmer groups, cooperatives) to gain more information about government assistance programs for small-scale farmers.

Farmer groups have been acknowledged for their important role in increasing productivity and income, transforming farming practices, and changing the market orientation. It is also proven to have a positive relationship with household food security (Tolno et al., 2015; Rahmadanih et al., 2018), social cohesion with regulatory, normative, and cultural cognitive elements activities for social life stability (Janssen \& Nonnenmann, 2017). It is also related to the performance and management practices (de Grip, 2015), particularly in informal learning processes of rural economic development (Marsick \& Volpe, 1999; Dotcenko et al., 2016).

Behavioral changes in the farmer institutions will emphasize the formal organizations' actions in promoting the sustainability agenda, such as investing and financing practices, particularly in food supply chains (Glover et al., 2014). Understanding institutional change and economic behavior will provide benefits in recognizing the stability process of change (M. L. Baba et al., 2012); in optimizing the usage of innovation by managing information, mediating information, educating users, and driving business units (Prawiranegara et al., 2015; Janssen \& Nonnenmann, 2017).

However, researchers identified dysfunctionality rates in the role of farmer institutions that stimulate excessive resistance of structural change due to interpersonal conflict. It is caused by management issues, personnel practices, work value structures (Beyers et al., 2008; Devon \& Andrew, 2018), investment constraints (Tolno et al., 2015), and the obsolescence of institutional functions for complying to their members' preferences (de Miranda et al,,2017). Besides, there are challenges in farmer institution structural changes, i.e. the question of whether and how they can adapt to these changes (Rezaei et al., 2017), internal and external factors of their members' behavior (Gray \& Kraenzle, 2002; Balmann et al., 2006), and potential forces that against the adaptation (Nilsson, 1997; Jiotsa et al., 2015).

Therefore, this paper aims to identify the determinant factors that change the behavior of independent palm smallholders by elaborating on the internal and external factors that affect their behavior in their institutions. The result is expected to optimize the role of farmer institutions, particularly independent palm smallholders in obtaining supplies and services, enhancing rural living, improving efficiency, and providing information on effective workgroups and benefits of their members and communities (Gray, T. W., \& Kraenzle, 2002).

\section{METHODOLOGY}

The research involved 100 independent palm oil farmers in Sambas Regency, West Kalimantan which are one of the highest numbers of independent palm smallholders that had the discrepancy of knowledge and competence levels (Nurliza et al., 2018; Nurliza, 2020). The data was collected in two steps. First, the researchers identified the characteristics of independent smallholders in farmer groups. These groups are initially rice farmer groups that had palm farms or converted their lands into palm farms (Sugiyono, 2003). Second, the researchers conducted an in-depth interview for completeness answer (Turner, 2010; Aboelmaged, 2018).

Next, the quantitative data was analyzed by applying the Structural Equation Model (SEM) using Lisrel software to test the hypothesis of the internal dan external factors in influencing independent palm smallholder behavior in their institutions. The internal factors that were being tested were age, education, participation level in the farmer institutions, farming experience, income, expense, and attitude (Baba et al., 2014; Tolno et al., 2015; Ullah et al., 2015; Mankad, 2016). Meanwhile, the 
external factors that were being tested were family encouragement, environment, ISPO (regulation), reward, institutional information, and the role of extension (Baba et al., 2014; Tolno et al., 2015; Jiotsa et al., 2015; Nilsson et al., 2016; Coster et al., 2017; Linés et al., 2018).

Structural Equation Model (SEM) generated two models, i.e. the measurement model and the structural model. The first model produced convergent validity and discriminant validity while the second model produced predictive validity in these following steps (Sarwono, 2006): (1) specifying model based on theory; (2) qualifying model for causal relationships; (3) converting flowcharts into a series of structural equations and measurement model specifications; (4) selecting matrix input and estimating techniques of model; (5) testing the validity and reliability using construct reliability (CR) with the value of more than or equal to 0.70 and variance extracted (VE) with the value of more than or equal to 0.50 (Wijanto, 2008); testing the standardized loadings factor with the value of more than 0.70 (Rigdon \& Ferguson, 1991) or more than 0.50 (Igbaria et al., 1997); (6) assessing the identified problem; (7) evaluating the model using the goodness of fit test; (9) re-specifying the model; (10) testing the goodness of fit for re-specification model; and (11) performing the interpretation model (Wijanto, 2008; Riadi, 2013).

\section{RESULTS AND DISCUSSION}

\section{The Farmers' Characteristics}

The findings show that independent palm smallholders' behavior in their institutions is determined by several factors, i.e. age, participation in farmer institutions, education, family members, playing jobs, income, and expense. Most of the smallholders are between 40 and 50-year-old. The palm smallholders' participation duration in their farmer groups is 24 years on average. Their educational backgrounds are between 6 and 9 years of formal school (graduate of elementary and junior high schools). Their family members are 3 people on average. Their main job is a farmer with a household income of less than and equal to 4,000,000 rupiahs per month. Their household expenditure is less than and equal to 1,500,000 rupiahs per month (see Table 1 in appendix).

Age reflected the smallholders' experience which usually brings knowledge (Lee et al., 2014) and social-influence effect on risk perception behavior (Hervé \& Mullet, 2009; Knoll et al., 2017). Older farmers consulted and participated more widely and are more favored compared to the younger ones in their institution (Oshagbemi, 2004).

In group participation duration, the cooperative societies' role in collective action as social capital is weak (Gilson, 2003; Liang et al., 2015). This characteristic of group participation for improving household livelihood is in contrast to a prior study (Taruvinga \& Fraser, 2009). Knowledge, training, and environmental policy information also play key roles in farmer activities (H. Liu \& Luo, 2018). The adoption of information technology (Suvedi et al., 2017) through education and training (Sullivan-Wiley \& Gianotti, 2018) can be an incentive for increasing the knowledge of independent palm smallholders (Lastra-Bravo et al., 2015).

In education, smallholders with higher education levels show better comprehension of knowledge advisories, sharing, and acting; faster and more often than those with lower education levels (Gowda \& Dixit, 2015). The role of job values plays in occupational choices and behavior in work settings. The broadness and stability of educational, cultural, and individual factors (Parandeh et al., 2015) also prove to influence the smallholder level of institution values (Arieli et al., 2019). 
Table 1. The farmers' characteristics

\begin{tabular}{|c|c|}
\hline Charachteristics & Percentage $(\%)$ \\
\hline \multicolumn{2}{|l|}{ Age (year): } \\
\hline$\leq 35$ & 9 \\
\hline$>35-40$ & 27 \\
\hline$>40-50$ & 53 \\
\hline$>50$ & 11 \\
\hline \multicolumn{2}{|c|}{ Participation in farmers' institution (year): } \\
\hline 24 & 55 \\
\hline 25 & 35 \\
\hline 26 & 10 \\
\hline \multicolumn{2}{|l|}{ Eduation (years): } \\
\hline$<6$ & 3 \\
\hline 6 & 36 \\
\hline 9 & 36 \\
\hline 12 & 21 \\
\hline 15 & 1 \\
\hline 17 & 3 \\
\hline \multicolumn{2}{|l|}{ Family members (People): } \\
\hline$\leq 2$ & 26 \\
\hline 3 & 31 \\
\hline 4 & 28 \\
\hline$\geq 5$ & 15 \\
\hline \multicolumn{2}{|l|}{ The main job: } \\
\hline Farmer & 93 \\
\hline Entrepreneur & 4 \\
\hline Officer & 3 \\
\hline \multicolumn{2}{|l|}{ Household income (Rp/month): } \\
\hline$\leq 4,000,000$ & 81 \\
\hline$>4,000,000-6,000,000$ & 16 \\
\hline$>6,000,000$ & 3 \\
\hline \multicolumn{2}{|l|}{ Household expenditure (Rp/month): } \\
\hline$\leq 1,500,000$ & 82 \\
\hline$>1,500,000-2,000,000$ & 13 \\
\hline$>2,000,000$ & 5 \\
\hline
\end{tabular}

In education, smallholders with higher education levels show better comprehension of knowledge advisories, sharing, and acting; faster and more often than those with lower education levels (Gowda \& Dixit, 2015). The role of job values plays in occupational choices and behavior in work settings. The broadness and stability of educational, cultural, and individual factors (Parandeh et al., 2015) also prove to influence the smallholder level of institution values (Arieli et al., 2019).

Then, household income was found to have a strong positive impact on household expenditure (Sekhampu \& Niyimbanira, 2013) as lifestyle changes (Tamboto, 2015) which effects on decision making. Full-time smallholders with long farming experience and high education background become increasingly dependent on farm income (Al-Rimawi et al., 2006) due to the trade-offs and labor allocation (Bjornlund et al., 2019) for maximizing the total household income.

\section{Independent Palm Smallholders' Behavior in Their Institutions}

The finding was interpreted after conduct the goodness of fit test (see Table 2 in appendix) for identifying the significant factors in the model for structural change in farmers' institutions. In the goodness of fit test, the re-specification model of independent palm smallholders' behaviors in their institution proved that there were sixteen criteria in the GOF test which had a good fit (see Figure 1 in appendix). 
Table 2. Goodness of fit test

\begin{tabular}{|c|c|c|c|}
\hline GOF Criteria & $\begin{array}{c}\text { Goodness of Fit Standard } \\
\text { Value }\end{array}$ & Estimate & Conclusion \\
\hline Chi Square $\left(\chi^{2}\right)$ & $\rho \geq 0,05$ & $\rho=0.011$ & marginal \\
\hline$x^{2} / D F$ & $1.0 \geq x \leq 5.0$ & 1.241 & good \\
\hline $\mathrm{NCP}$ & $\begin{array}{l}\text { Small value with narrow } \\
\text { intervals }\end{array}$ & $\begin{array}{c}19.75 \\
(7.59 ; 43.35)\end{array}$ & good \\
\hline $\mathrm{SNCP}(\mathrm{NCP} / \mathrm{n})$ & Small value & 0.519 & good \\
\hline RMSEA & $\leq 0.08$ & $\begin{array}{c}0.034 \\
1.12\end{array}$ & good \\
\hline ECVI & $\begin{array}{l}\text { Small value and close to } \\
\text { Saturated ECVI }\end{array}$ & $\begin{array}{c}(1.02 ; 1.28) \\
S=1.23 \\
I=5.94\end{array}$ & good \\
\hline AIC & $\begin{array}{l}\text { Small value and close to } \\
\text { Saturated AIC }\end{array}$ & $\begin{array}{c}\mathrm{M}=169.47 \\
\mathrm{~S}=178.42 \\
\mathrm{I}=887.82\end{array}$ & good \\
\hline CAIC & $\begin{array}{l}\text { Small value and close to } \\
\text { Saturated CAIC }\end{array}$ & $\begin{array}{l}M=404.96 \\
S=567.62 \\
I=935.93\end{array}$ & good \\
\hline NFI & $\geq 0.90$ & 0.90 & good \\
\hline NNFI & $\geq 0.90$ & 0.94 & good \\
\hline PNFI & $\geq 0.90$ & 0.65 & poor \\
\hline CFI & $\geq 0.90$ & 0.91 & good \\
\hline IFI & $\geq 0.90$ & 0.94 & good \\
\hline RFI & $\geq 0.90$ & 0.90 & good \\
\hline GFI & $\geq 0.90$ & 0.95 & good \\
\hline AGFI & $\geq 0.90$ & 0.90 & poor \\
\hline PGFI & $0-1$ & 0.37 & good \\
\hline RMR & $\leq 0.05$ & 0.018 & good \\
\hline $\mathrm{CN}$ & $\geq 200$ & 189.56 & marginal \\
\hline
\end{tabular}

The unobserved variable or latent construct variable is independent palm smallholders' behavior (see Figure 1 in appendix) can be estimated through the observed variable or their indicators of internal and external factors. In the structural model, the internal factor has no significant influence. Contrary to Othman et al. (2012), the older age group has a lower essence of commitment for their institution performance.

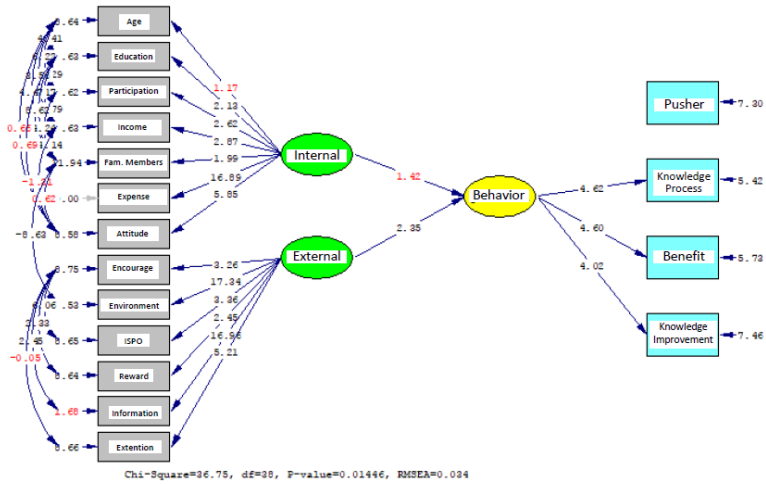

(a) t-value

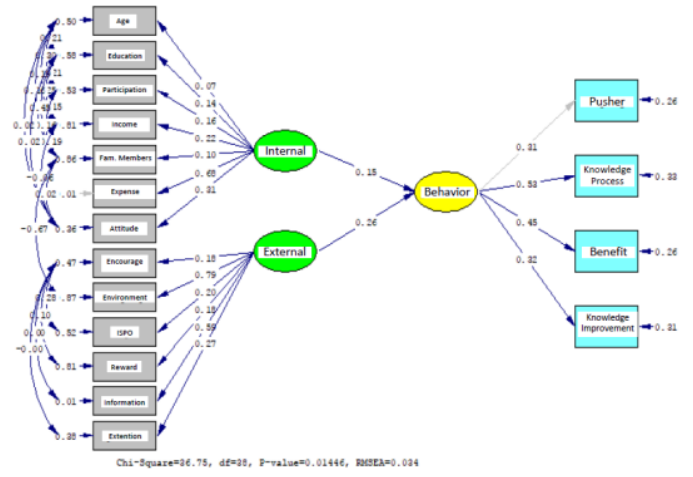

(b) coefficient estimate

Figure 1. (a) t-value and (b) estimate coefficient of Independent palm smallholders' behavior in their institution 
However, there is a positive influence on external factors. It means that external factors will increase the independent palm smallholders' behavior. The magnitude of the external factor's influence in the structural model (0.26) shows the changing contributions in smallholders' behavior. An increase in $1 \%$ of external factors lead to an increase in $0.26 \%$ of smallholders' behavior in their institutions. The contribution of the external factor on smallholders' behavior is presented in Table 3 in the appendix.

Table 3. The positive contribution of external factors on smallholders' behavior in their institution

\begin{tabular}{lc}
\hline \multicolumn{1}{c}{ External factor contributions } & Percentage $\mathbf{( \% )}$ \\
\hline Family encouragement & 66 \\
Surround environment & 56 \\
ISPO & 59 \\
Reward & 36 \\
Institutional information & 62 \\
The role of extension & 57 \\
\hline
\end{tabular}

Education, participation in their institutions, farming experience, income, expense, and attitude have different levels in predicting internal factors because of the following reasons, i.e. social influences do not facilitate their relationship, exceptional characteristics of the region (Aggelopoulos et al., 2016), a mismatch between perceived risk sources and risk management strategies (Duong et al., 2019).

Family encouragement, surrounding environment, ISPO, reward, institutional information, and the role of the extension are important indicators in external factors that influence independent palm smallholders' behavior in their institutions. The highest influence of external factors is the environment $(0.79)$, followed by institutional information (0.59), the role of extension (0.27), ISPO (0.20), reward $(0.18)$ and family encouragement (0.18).

Farmers' responses to behavioral changes are source from the surrounding environment that generated from a combination of attitudes towards behavior, perception of others towards behavior (subjective norms), and the degree of control one thinks one has over the decision to carry out the behavior (perceived behavioral control) (Rehman et al., 2008). Meanwhile, social norms and uncertainty that are related to the importance scale of information and expected farm profits also play a role in decision-making (Liu et al., 2018). Thus, decision making in agriculture is becoming knowledgeintensive and increasingly complex (FAO, 2017).

On the other hand, smallholders face constraints on how to access markets and financial services, reduce the risks of human and physical capital, access information to improve their family livelihoods and society (Harvey et al., 2014). Therefore, the intervention programs that focus on strengthening independent palm smallholder institutions and innovation will stimulate change in farmers' behavior. It will also link social capital with stakeholders along with agricultural value chains (Kolade \& Harpham, 2014; JI et al., 2018).

ISPO is a mandatory regulation for sustainable certification standards in Indonesia provides information that is in line with applicable provisions, particularly on the management and monitoring of the environment (Nurliza et al., 2019). Therefore, ISPO should be seen as a way to provide sustainable knowledge exchange activities and more than just simply providing information (Rose et al., 2018). Literature also confirms that the utilization of monetary incentives enhances performance through behavior changes in institutions (Bitzer, 2016). Ejembi \& Obekpa (2017) stated that family encouragement and the environment will ensure the society to behave in line with their social structure and society's culture.

Therefore, knowledge exchange in social and institutional change needs to shift social norms and attitudes through formal or informal networks communication. It will increase their level of confidence and control in performing a particular behavior (Rose et al., 2018). Another way is to identify and create links with institutional buyers and potential agro-processing entrepreneurs to provide better prices for products and to ensure a steady market (Ferris et al., 2014; Dube et al., 2018); 
links farmers to appropriate formal saving schemes (Agri-Profocus, 2011) and financial products that are suitable for their value chains (F\&BKP, NpM, 2014; Consiglieri-Private-Limited, 2016).

\section{CONCLUSIONS}

Most of the independent palm smallholders are between the age of 40 and 50 years old with 24 years of membership in their institutions, having 6 and 9 years of education or elementary and junior high school graduates, and 3 people of family members. Their main job is a farmer with a household income of less or equal to 4,000,000 rupiahs per month. Their household expenditure is less and equal to $1,500,000$ rupiahs per month. The results confirm that the internal factors do not have any influence on farmer's behavior in their institution because of less social influences in their relationships, exceptional characteristics of the region, a mismatch between perceived risk sources, and risk management strategies. However, the external factors have a positive influence on their behavior in their institution. The highest external influencer is the surrounding environment, followed by institutional information, the role of extension, ISPO, reward, and family encouragement. Therefore, behavior changes of independent palm smallholders in their institutions need the support of knowledge exchange through formal or informal networks communication, the linkages with institutional buyers and potential agro-processing entrepreneurs, link to appropriate formal saving schemes, and financial products in their value chains.

\section{ACKNOWLEDGMENTS}

We would like to express sincere gratitude to the Directorate of Research and Community Service, Directorate-General for Strengthening Research and Development of the Ministry of Research, Technology (RISTEK), and Higher Education (DIKTI) for funding this research through the applied research scheme 2019-2021.

\section{REFERENCES}

Aboelmaged, M. (2018). The drivers of sustainable manufacturing practices in Egyptian SMEs and their impact on competitive capabilities: A PLS-SEM model. Journal of Cleaner Production. https://doi.org/10.1016/j.jclepro.2017.12.053

Aggelopoulos, S., Karelakis, C., Tsantopoulos, G., Pavloudi, A., \& Seitanis, P. (2016). Farmers' perceptions and attitudes towards the development of the sheep and goat sector in the Greek region of Evros. SpringerPlus. https://doi.org/10.1186/s40064-016-2811-3

Agri-Profocus. (2011). A guide for smallholder farmers on saving, acessing credit, and effectively managing money for improved livelihoods. https://www.fsnnetwork.org/sites/default/files/a_guide_for_small_holder_farmers_on_saving_ac cessing_credit_and_effectively_managing_money_for_improved_livelihoods.pdf

Arieli, S., Sagiv, L., \& Roccas, S. (2019). Values at Work: The Impact of Personal Values in Organizations. Applied Psychology, 69(4), 1-46.

Baba, M. L., Blomberg, J., LaBond, C., \& Adams, I. (2012). New Institutional Approaches to Formal Organizations. In A Companion to Organizational Anthropology. https://doi.org/10.1002/9781118325513.ch3

Baba, S., Dagong, M. I. A., \& Risal, M. (2014). Some factors affecting intensive rearing adoption on beef cattle farmers in Wajo regency, South Sulawesi Province. Journal of the Indonesian Tropical Animal Agriculture. https://doi.org/10.14710/jitaa.39.4.235-241

Balmann, A., Dautzenberg, K., Happe, K., \& Kellermann, K. (2006). On the dynamics of structural change in agriculture: Internal frictions, policy threats and vertical integration. In Outlook on Agriculture. https://doi.org/10.5367/000000006777641543

Beyers, J., Eising, R., \& Maloney, W. (2008). Researching interest group politics in Europe and elsewhere: Much we study, little we know? West European Politics. https://doi.org/10.1080/01402380802370443 
Bitzer, V. (2016). Incentives for enhanced performance of agricultural extension systems. In Kit Suistanable Economic Development \& Gender.

Bjornlund, H., Zuo, A., Wheeler, S. A., Parry, K., Pittock, J., Mdemu, M., \& Moyo, M. (2019). The dynamics of the relationship between household decision-making and farm household income in small-scale irrigation schemes in southern Africa. Agricultural Water Management. https://doi.org/10.1016/j.agwat.2018.10.002

Chandre Gowda, M. J., \& Dixit, S. (2015). Influence of farmers educational level on comprehending, acting-upon and sharing of agro advisories. Journal of Agriculture and Rural Development in the Tropics and Subtropics.

Consiglieri-Private-Limited. (2016). An in-depth study on Farmer's Behavior Change, Drivers and Barriers as well as 'Spontaneous' Impact on Family and Neighbors of SaFaL. https://www.solidaridadnetwork.org/sites/solidaridadnetwork.org/files/publications/Annex BStudy on Farmer\%27s Behavior Change.pdf

Coster, J. E., Turner, J. K., Bradbury, D., \& Cantrell, A. (2017). Why Do People Choose Emergency and Urgent Care Services? A Rapid Review Utilizing a Systematic Literature Search and Narrative Synthesis. In Academic Emergency Medicine. https://doi.org/10.1111/acem.13220

de Grip, A. (2015). The importance of informal learning at work. IZA World of Labor. https://doi.org/10.15185/izawol.162

de Miranda, R. P., Thiam, A., \& Klug, I. (2017). Targeting farmers in institutional procurement programmes: case study of the PAA Africa Programme in Senegal. http://www.fao.org/3/ai7441e.pdf

Devon, C., \& Paul Andrew, B. (2018). Management of Interpersonal Conflict between Principals and Teachers in Selected Secondary Schools in Bermuda. Insights of Anthropology. https://doi.org/10.36959/763/489

Dotcenko, I. G., Evtodieva, T. E., Polynova, L. V., \& Alontceva, E. A. (2016). The Concept of Informal Learning in the Organization. IEJME - MATHEMATICS EDUCATION, 11(7), 26262638.

Dube, S. C., Nair, R. d., Nkhonjera, M., \& Tempia, N. (2018). Structural transformation in agriculture and agro. https://www.researchgate.net/publication/329137193_Structural_Transformation_in_South_Afri ca_Moving_Towards_a_Smart_Open_Economy_for_All

Duong, T. T., Brewer, T., Luck, J., \& Zander, K. (2019). A global review of farmers' perceptions of agricultural risks and risk management strategies. In Agriculture (Switzerland). https://doi.org/10.3390/agriculture9010010

Ejembi, S. A., \& Obekpa, H. O. (2017). EFFECTS OF SOCIO-CULTURAL FACTORS ON EFFECTIVE AGRICULTURAL TRAINING PROGRAMS FOR FARMERS BY THE BENUE STATE AGRICULTURAL DEVELOPMENT AUTHORITY IN ZONE C. Journal of Asian Rural Studies. https://doi.org/10.20956/jars.v1i1.726

F\&BKP, NpM, \& A. (2014). Finance for Smallholder: Opportunities for risk management by linking financial institutions and producer organisations. https://agriprofocus.com/upload/Summary_Report_Finance_for_Smallholders1430244415.pdf

FAO. (2017). Information and Communication Technology (ICT) in Agriculture. http://www.fao.org/3/a-i7961e.pdf

Ferris, S., Robbins, P., Best, R., Seville, D., Buxton, A., Shriver, J., \& Wei, E. (2014). Linking Smallholder Farmers to Markets and the Implications for Extension and Advisory Services. https://www.agrilinks.org/sites/default/files/resource/files/MEAS Discussion Paper 4 - Linking Farmers To Markets - May 2014.pdf

Gilson, L. (2003). Trust and the development of health care as a social institution. Social Science and Medicine. https://doi.org/10.1016/S0277-9536(02)00142-9

Glover, J. L., Champion, D., Daniels, K. J., \& Dainty, A. J. D. (2014). An Institutional Theory Jurnal Penyuluhan | Vol. 17 (01) 2021 | 8 
perspective on sustainable practices across the dairy supply chain. International Journal of Production Economics. https://doi.org/10.1016/j.ijpe.2013.12.027

Gray, T. W., \& Kraenzle, C. A. (2002). Problems and Issues Facing Farmer Cooperatives. https://www.rd.usda.gov/files/RR192.pdf

Harvey, C. A., Rakotobe, Z. L., Rao, N. S., Dave, R., Razafimahatratra, H., Rabarijohn, R. H., Rajaofara, H., \& MacKinnon, J. L. (2014). Extreme vulnerability of smallholder farmers to agricultural risks and climate change in Madagascar. Philosophical Transactions of the Royal Society B: Biological Sciences. https://doi.org/10.1098/rstb.2013.0089

Hervé, C., \& Mullet, E. (2009). Age and factors influencing consumer behaviour. International Journal of Consumer Studies. https://doi.org/10.1111/j.1470-6431.2009.00743.x

Igbaria, M., Zinatelli, N., Cragg, P., \& Cavaye, A. L. M. (1997). Personal computing acceptance factors in small firms: A structural equation model. MIS Quarterly: Management Information Systems. https://doi.org/10.2307/249498

Janssen, B., \& Nonnenmann, M. W. (2017). New Institutional Theory and a Culture of Safety in Agriculture. Journal of Agromedicine. https://doi.org/10.1080/1059924X.2016.1249444

JI, C., CHEN, Q., Trienekens, J., \& WANG, H. tao. (2018). Determinants of cooperative pig farmers' safe production behaviour in China - Evidences from perspective of cooperatives' services. Journal of Integrative Agriculture. https://doi.org/10.1016/S2095-3119(18)62058-1

Jiotsa, A., Okia, T. M., \& Yambene, H. (2015). Cooperative movements in the Western Highlands of Cameroon: Constraints and adaptation strategies. Revue de Geographie Alpine. https://doi.org/10.4000/rga.2764

Knoll, L. J., Leung, J. T., Foulkes, L., \& Blakemore, S. J. (2017). Age-related differences in social influence on risk perception depend on the direction of influence. Journal of Adolescence. https://doi.org/10.1016/j.adolescence.2017.07.002

Kolade, O., \& Harpham, T. (2014). Impact of cooperative membership on farmers' uptake of technological innovations in Southwest Nigeria. Development Studies Research. https://doi.org/10.1080/21665095.2014.978981

Lastra-Bravo, X. B., Hubbard, C., Garrod, G., \& Tolón-Becerra, A. (2015). What drives farmers' participation in EU agri-environmental schemes?: Results from a qualitative meta-analysis. Environmental Science \& Policy, 54, 1-9.

Lee, A., Garbutcheon-Singh, K. B., Dixit, S., Brown, P., \& Smith, S. D. (2014). The Influence of Age and Gender in Knowledge, Behaviors and Attitudes Towards Sun Protection: A Cross-Sectional Survey of Australian Outpatient Clinic Attendees. American Journal of Clinical Dermatology. https://doi.org/10.1007/s40257-014-0106-4

Liang, Q., Huang, Z., Luc, H., \& Wangd, X. (2015). Social capital, member participation, and cooperative performance: Evidence from China's Zhejiang. International Food and Agribusiness Management Review.

Linés, C., Iglesias, A., Garrote, L., Sotés, V., \& Werner, M. (2018). Do users benefit from additional information in support of operational drought management decisions in the Ebro basin? Hydrology and Earth System Sciences. https://doi.org/10.5194/hess-22-5901-2018

Liu, H., \& Luo, X. (2018). Understanding farmers' perceptions and behaviors towards farmland quality change in northeast China: A structural equation modeling approach. Sustainability (Switzerland). https://doi.org/10.3390/su10093345

Liu, T., Bruins, R. J. F., \& Heberling, M. T. (2018). Factors influencing farmers' adoption of best management practices: A review and synthesis. In Sustainability (Switzerland). https://doi.org/10.3390/su10020432

Mankad, A. (2016). Psychological influences on biosecurity control and farmer decision-making. A review. Agronomy for Sustainable Development, 36(2), 40.

Marsick, V. J., \& Volpe, M. (1999). The nature and need for informal learning. Advances in 
Developing Human Resources. https://doi.org/10.1177/152342239900100302

Nilsson, D., Baxter, G., Butler, J. R. A., \& McAlpine, C. A. (2016). How do community-based conservation programs in developing countries change human behaviour? A realist synthesis. In Biological Conservation. https://doi.org/10.1016/j.biocon.2016.05.020

Nilsson, J. (1997). Inertia in Cooperative Remodeling. Journal of Cooperatives, NCERA-210, 12, 62 73.

Nurliza, Dolorosa E., S. U. E. (2018). The Discrepancy between Knowledge and Competency of Independent Smallholder Farmer's for Sustainable Palm Oil. Jurnal Penyuluhan, 14(2), 209221.

Nurliza. (2020). Creating Strategic Competence of Independent Smallholders for Sustainable Palm Oil. Jurnal Penyuluhan, 16(1), 1-15.

Nurliza, Dolorosa, E., \& Suryadi, U. E. (2019). Farmers' organizations model of independent smallholders in sustainable palm oil certification. Pertanika Journal of Social Sciences and Humanities.

Oshagbemi, T. (2004). Age influences on the leadership styles and behaviour of managers. Employee Relations. https://doi.org/10.1108/01425450410506878

Othman, A., Kari, F., Jani, R., \& Hamdan, R. (2012). Factors influencing cooperative membership and share increment: an application of the logistic regression analysis in the Malaysian cooperatives. World Review of Business Research.

Parandeh, A., Khaghanizade, M., Mohammadi, E., \& Nouri, J. M. (2015). Factors Influencing Development of Professional Values Among Nursing Students and Instructors: A Systematic Review. Glob J Health Sci., 7(2), 284-293.

Prawiranegara, D., Sumardjo, Sri, D. P. L., \& Harijati, S. (2015). Strengthening Role of Farmer Institution in Enhance of Innovation Capability Based on ICT in West Java Province, Indonesia. International Journal of Humanities and Social Science. https://doi.org/10.18551/rjoas.201903.11

Rahmadanih, Bulkis, S., Arsyad, M., Amrullah, A., \& Viantika, N. M. (2018). Role of farmer group institutions in increasing farm production and household food security. IOP Conference Series: Earth and Environmental Science. https://doi.org/10.1088/1755-1315/157/1/012062

Rehman, T., Garforth, C., McKemey, K., Yates, C., \& Rana, R. B. (2008). Farmers' behavioural inclinations and their influence on the anticipated response to the reform of the Common Agricultural Policy in England. Journal of Farm Management, 13(4), 1-29.

Rezaei, A., Salmani, M., Razaghi, F., \& Keshavarz, M. (2017). An empirical analysis of effective factors on farmers adaptation behavior in water scarcity conditions in rural communities. International Soil and Water Conservation Research. https://doi.org/10.1016/j.iswcr.2017.08.002

Riadi, E. (2013). Aplikasi Lisrel untuk Penelitian Analisis Jalur. CV. Andi Offset.

Rigdon, E. E., \& Ferguson, C. E. (1991). The Performance of the Polychoric Correlation Coefficient and Selected Fitting Functions in Confirmatory Factor Analysis with Ordinal Data. Journal of Marketing Research. https://doi.org/10.2307/3172790

Rose, D. C., Keating, C., \& Morris, C. (2018). ). Understand how to influence farmers' decisionmaking behaviour: a social science literature review. https://projectblue.blob.core.windows.net/media/Default/ImportedPublicationDocs/FarmersDecis ionMaking_2018_09_18.pdf

Sarwono, J. (2006). Metode Penelitian Kuantitatif dan Kualitatif. Graha Ilmu.

Sekhampu, T. J., \& Niyimbanira, F. (2013). Analysis Of The Factors Influencing Household Expenditure In A South African Township. International Business \& Economics Research Journal (IBER). https://doi.org/10.19030/iber.v12i3.7671

Sh. Al-Rimawi, A., Karablieh, E. K., Al-Qadi, A. S., \& Al-Qudah, H. F. (2006). Farmers' Attitudes and Skills of Farm Business Management in Jordan. The Journal of Agricultural Education and 
Extension. https://doi.org/10.1080/13892240600915462

Sugiyono. (2003). Metode Penelitian Bisnis. Alfabeta.

Sullivan-Wiley, K. A., \& Short Gianotti, A. G. (2018). Pursuing productivity gains and risk reduction in a multi-hazard landscape: A case study from eastern Uganda. Land Use Policy. https://doi.org/10.1016/j.landusepol.2018.08.035

Suvedi, M., Ghimire, R., \& Kaplowitz, M. (2017). Farmers' participation in extension programs and technology adoption in rural Nepal: a logistic regression analysis. In Journal of Agricultural Education and Extension. https://doi.org/10.1080/1389224X.2017.1323653

Tamboto, H. J. (2015). The implication of farmers' behavior to the household economic income through economic decision (The study of farmers' household in minahasa regency). International Journal of Business and Management Invention, 4(3), 10-19.

Taruvinga, B., \& Fraser, G. C. (2009). An analysis of institutional and technical factors influencing agricultural marketing amongst smallholder farmers in the Kat River Valley, Eastern Cape Province, South Africa. African Journal of Agricultural Research, 4(11), 1129-1137.

Tolno, E., Kobayashi, H., Ichizen, M., Esham, M., \& Balde, B. S. (2015). Economic Analysis of the Role of Farmer Organizations in Enhancing Smallholder Potato Farmers' Income in Middle Guinea. Journal of Agricultural Science. https://doi.org/10.5539/jas.v7n3p123

Turner, D. W. (2010). Qualitative interview design: A practical guide for novice investigators. Qualitative Report.

Ullah, R., Shivakoti, G. P., \& Ali, G. (2015). Factors effecting farmers' risk attitude and risk perceptions: THE case of Khyber Pakhtunkhwa, Pakistan. International Journal of Disaster Risk Reduction. https://doi.org/10.1016/j.ijdrr.2015.05.005

Wijanto, S. H. (2008). Structural Equation Modeling dengan Lisrel 8.8. Graha Ilmu. 